\title{
Managing the equilibrium state of housing affordability
}

\author{
Ariadna Kirillova, ${ }^{1, *}$ \\ ${ }^{1}$ Moscow State University of Civil Engineering, 26, Yaroslavskoye Shosse, 109377, Moscow, Russia
}

\begin{abstract}
The subject of the study is the organizational and economic aspects of managing the equilibrium state of housing affordability for the population during construction. The analysis shows that despite the successful development of the housing sector and the functioning of the housing market, housing affordability is differentiated, which is manifested in unsatisfactory housing conditions of a significant part of low-income and other established categories of citizens. The aim of the study is to improve the processes of ensuring targeted consistent housing policies already at the construction stage to increase not only market, but also social affordability of housing. Materials and methods include a methodological approach, which involves the construction of a model of interaction between the investor and local authorities during the construction process in order to accelerate the solution of the problem of increasing housing affordability for the low-income citizens on the basis of ensuring the required volumes of housing construction in accordance with the main legislative formats. The optimization of the coordination model of the interests of investors and the municipality during the construction in this social housing cluster is ensured through the implementation of mechanisms to reduce the expenses of investors to obtain a land plot, as well as the proposed measures that increase the social accessibility of housing. The task is to ensure the balance and comprehensiveness of the market and social affordability of housing for various categories of citizens by expanding the list of powers of municipalities and financing their implementation for the construction of social housing facilities.
\end{abstract}

\section{Introduction}

The implementation of the National project "Housing and Urban Environment" requires more substantiated studies of the structure of housing construction, increasing the affordability of housing, including mechanisms for providing social housing for lowincome citizens and other legally defined categories of the population. The goal to ensure the improvement of living conditions of at least 5 million people in the period up to 2024 requires research and ensuring an equilibrium state in modern conditions, i.e. the balance and proportionality of housing affordability for various categories of citizens who need to improve housing conditions. Over the past 30 years, the country has created an institutional

\footnotetext{
${ }^{*}$ Corresponding author: kirillova_an@mail.ru
} 
housing market system, mortgage lending mechanisms are functioning effectively, which allows a significant part of the population to improve housing conditions in the housing market. At the same time, the low scientific effectiveness of implementing social and rental housing programs for certain categories of the population continues to remain an urgent scientific problem, which requires the study of methods to accelerate the solution of this problem $[1,2,3]$.

In scientific publications, the authors prove the development of an unstable trend caused by the transition to financing housing construction on escrow accounts and the growth of bankruptcies of business entities, the insufficient rate of planned commissioning of facilities, higher housing prices and lower housing affordability. Under these conditions, the important task is to ensure a targeted, consistent housing policy already at the construction stage with the interaction of investors with the governing bodies regulating the improvement of housing conditions and increasing the availability of housing for citizens.

\section{Materials and Methods}

The paper proposes a methodological approach that involves decomposing the functioning of the housing market during construction in accordance with the basic subsystems within the framework of the developed municipal territorial and parametric market model, which includes an assessment of the investment attractiveness of the municipality, structural components of the housing market, parametric segments of supply and demand, price situation, financial (cash) flows, ownership of housing during the life cycle of the property, and a system of parameters that determine the initial characteristics of the housing market, on the basis of which indicators of accessibility to improve the living conditions of the population are calculated by the category of their need, which is presented in the developed scheme in Figure 1.

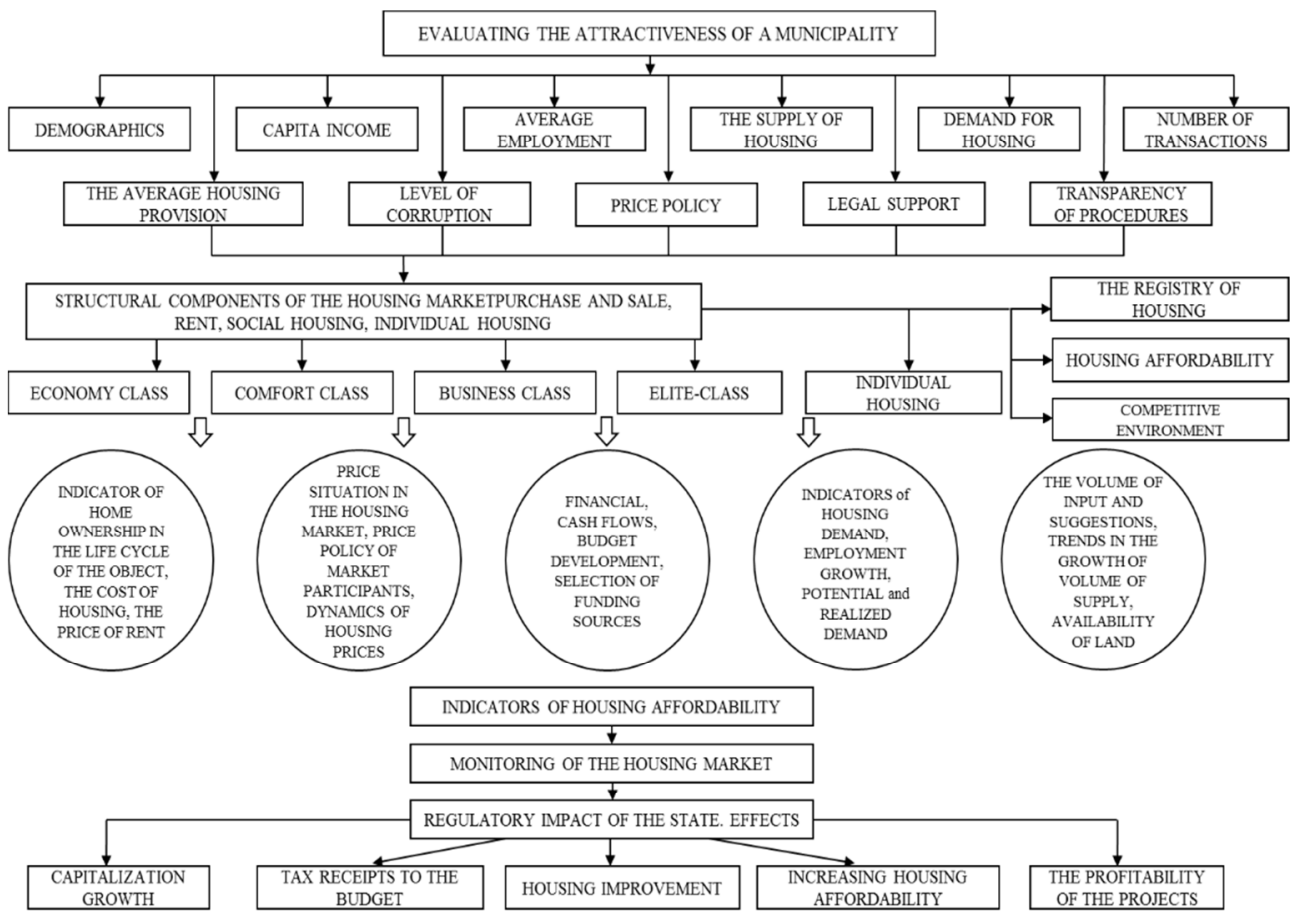

Fig. 1. Scheme of the municipal territorial and parametric model of the housing market. 
Systematic monitoring of the dynamics of the housing market allows developing regulatory state impacts on individual market segments, which is presented in the developed structural diagram of the regulatory state impact on the construction and housing market in Figure 2.

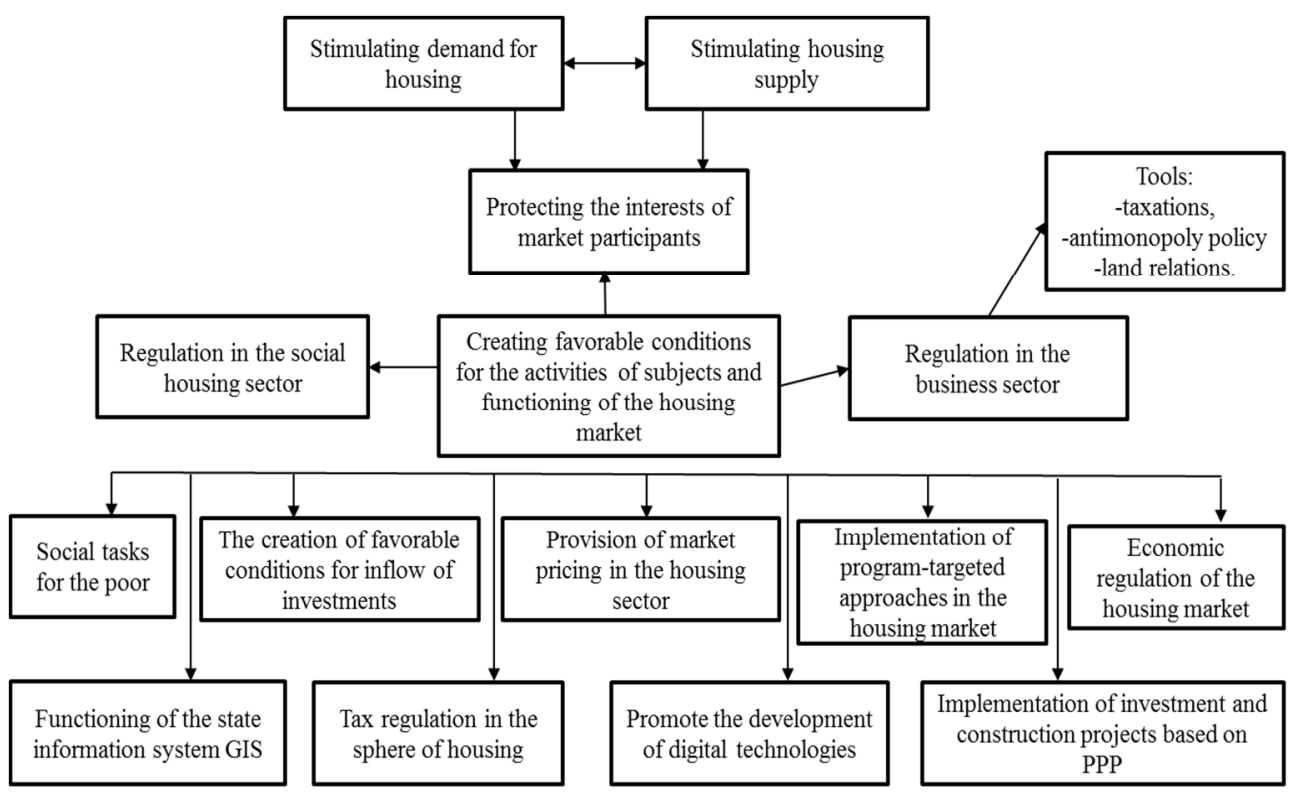

Fig. 2. Structural diagram of the regulatory state impact on the construction and housing market.

The modeling process required not only an analysis of the interaction of structural components and parametric indicators of the housing market, but also the task of methodically focusing the process of subjective activity in construction, taking into account the significant influence of the principles of consistency of interests of investors, local governments and households on the equilibrium state of housing affordability [5,6].

The analysis involved the development of an organizational and economic model of the housing market, which determines the consistency of the interests of the investor and the authorities, taking into account the following indicators used in the model:

$\mathrm{S}$ - the volume of living space built by the developer (investor);

$\mathrm{I}$ - own investment resources of the developer;

$\mathrm{K}$ - the necessary volumes of lending to housing;

Ko - recommended limit on borrowed funds;

q - guaranteed rate of return;

$\mathrm{r}$ - the interest rate for obtaining a loan;

C - construction cost of 1 sq.m. of housing;

$\mathrm{C}_{1 \text { max. }}$ - the maximum market sale price of 1 sq.m. of living space by the developer (investor);

$\mathrm{C}_{2}$ - the minimum market sale price of 1sq.m of living space by the developer (investor);

$\mathrm{Sc}$ - the amount of living space planned under the contract for transfer to state or municipal ownership for subsequent distribution in the prescribed manner to citizens in need;

$\mathrm{d}$ - the share of housing transferred to the ownership of the municipality from the volume of the living space commissioned by the developer (investor)

$\mathrm{P} 1$, - the probability of housing sales at the price of $\mathrm{C}_{1}$; 
$\mathrm{P} 2$, - the probability of housing sales at the price of $\mathrm{C}_{2}, \mathrm{I}=1-2$.

For the introduced variables, the following relation will be valid:

$\mathrm{Q}<\mathrm{r}_{\mathrm{i}}, \quad \mathrm{K}<\mathrm{Ko}, \mathrm{P}_{1}+\mathrm{P}_{2}=1$, values of $\mathrm{P}_{1}, \mathrm{P}_{2}$, are taken by expert method.

Based on the introduced notation, it is possible to create a model of the following form:

$$
\begin{gathered}
\frac{(1-\mathrm{d}) * \mathrm{~S}}{C} \sum \text { PiCimax } \\
\mathrm{d} \mathrm{S}=\mathrm{Sc}, \mathrm{K}=\mathrm{SC}-\mathrm{I} \leq \mathrm{Ko} \\
(1-\mathrm{d}) * \mathrm{~S} \sum \text { PiCi }(\mathrm{SC}-\mathrm{I}) *(1+\mathrm{r}) \geq \mathrm{I}(1+\mathrm{q}) \\
\sum \mathrm{Ri}=1, \mathrm{~b}>0, \mathrm{~S}>0
\end{gathered}
$$

The optimality criterion will consist of $\mathrm{dS}=\mathrm{Sc}, \mathrm{K}=\mathrm{SC}-\mathrm{I} \leq \mathrm{Ko}$ to ensure the equilibrium state of interests of the investor and local governments. The criterion for the investor is to maximize the expected income and the planned profit from the sale of the remaining housing after the transfer to the authorities

$$
\mathrm{C}_{1} *(1-\mathrm{d}) * \mathrm{P}_{1} \longrightarrow \max
$$

For local governments, the criterion of optimality is the maximizing proportion of the volume of constructed housing transferred from the investor.

$$
\mathrm{S} * \mathrm{~d} * \mathrm{P}_{1} \longrightarrow \max
$$

Moreover, the model of the equilibrium state of market affordability of housing may look like:

$$
\mathrm{C}_{1}(1-\mathrm{d}) * \mathrm{P}_{1}+\mathrm{S} * \mathrm{~d} * \mathrm{P}_{1} \mathrm{C}_{1}=\mathrm{S} \mathrm{C}_{1} \mathrm{P}_{1}
$$

\section{Results}

Given the Sc, which determines the needs of the governing bodies, this model task may not have a solution for the investor in modern conditions (with positive experience in Moscow and other regions) due to the disadvantage of investing in the above projects with obviously low profitability. In this case, it is necessary to introduce a regulatory impact on the revision of the share of the volume of housing built for the municipality based on the solution of an optimized model for the coordination of interests in this social housing cluster by implementing mechanisms to reduce expenses of the investors in order to ensure an equilibrium state of housing affordability in this municipal social housing cluster. To this end, in order to reduce expenses of the investor in the process of obtaining a land plot $y$ for housing construction, municipal authorities can make a decision on its allocation on the basis of preliminary coordination of the location of a residential building without an auction, which is directly related to the need to improve the living conditions of the population. The process of developing the optimal solution is completed if the search for the values of $b$ and $B$ is defined. Additional measures ensuring social accessibility of housing may include an increase in the list of powers of municipalities and financing of their implementation for the construction of housing facilities for social purposes, assistance in the formation of a housing and construction cooperation fund, the development of non-profit forms of construction and urban crowdfunding, justification of models for the construction of new types of multifunctional complexes (MFC) of the joint social housing and commercial area, including, along with the sale of commercial space, social and rental housing on the principles of municipal-private partnership. At the same 
time, subsidizing tools and other forms of support for ensuring social accessibility of housing for low-income categories of citizens should be used more widely [4].

\section{Conclusions}

The development of construction and housing programs is a multidimensional task regulated by federal law, which combines such social areas as relocating citizens from apartment buildings recognized as dangerous in the established order, providing housing for young families, orphans and children left without parental care, as well as persons among them, improving the living conditions of large families, providing housing for military personnel and certain categories of citizens, providing housing for citizens registered in the list for improving housing conditions under social and commercial employment contracts, social mortgages, and the use of maternity capital. The task is to ensure the balance and complexity of market and social affordability of housing for various categories of citizens.

\section{References}

1. N. Yaskova, Nedvizhimost ekonomika, upravlenie 4 (2019)

2. N. Kosareva, T. Polidi, A. Puzanov, Zhilishchnaya politika i ekonomika v Rossii: rezultaty $i$ strategiya razvitiya (NIU VSHE, Moscow, 2015)

3. P. Grabovyj, Servejing: organizaciya, ekspertiza, upravlenie. Ekspertiza nedvizhimosti i stroitelnyj control (Moscow, 2015)

4. A. Kirillova, O. Prytkova, E3S Web of Conferences 33, 03059 (2018) https://doi.org/10.1051/e3sconf/20183303059

5. M.V. Lvova, European research: Innovation in science, education. XXXIX International Scientific and Practical Conference (London, 2018)

6. W.T. Yang, Natural hazards and earth system sciences 15-4 (2015) 